\title{
Физиология
}

DOI: $10.14529 / \mathrm{hsm} 190101$

\section{EFFECTS OF A 6-WEEK CONTROLED EXERCISE PROGRAM AND SEMI-CONTROLED DIET ON BODY FAT AND SKELETAL MUSCLE MASS IN ADULTS}

\author{
F. Kukić1 , filip.kukic@gmail.com, ORCID ID: 0000-0002-8625-5375, \\ N. Todorović ${ }^{2}$, nemanja.tod@hotmail.com, ORCID ID: 0000-0003-4741-0966, \\ N. Cvijanović ${ }^{2}$, nenadcvijanovic89@gmail.com, ORCID ID: 0000-0002-7196-6342 \\ ${ }^{1}$ Police Sports Education Center, Abu Dhabi Police, United Arab Emirates, \\ ${ }^{2}$ Kubo Training Center, Belgrade, Serbia
}

\begin{abstract}
Aim. To investigate the effects of a 6-week of controlled exercise program followed by a semi-controlled dietary regimen on indicators of body fat mass (BF) and skeletal muscle mass (SMM) of adults. Materials and methods. The sample consisted of 28 particpants with the main characteristics of the sample being: age $=29.70 \pm 8.35$ years, body height $(\mathrm{BH})=177.35 \pm 9.36 \mathrm{~cm}$, and body mass $(\mathrm{BM})=105.20 \pm 27.06 \mathrm{~kg}$. Body composition parameters, BM, body fat mass (BF), trunk fat (TF), skeletal muscle mass (SMM), percent of body fat (PBF), percent of skeletal muscle mass (PSMM), body mass index (BMI), and index of hypokinesia (IH) were collected before and after six weeks of exercise program and semi-controlled diet regimen. A Paired sample T-test and effect size (ES) were used to determine the effects and their magnitude of the treatment applied. Results. A 6-week treatment significantly affected investigated variables, wherein $\mathrm{BF}$ $(-6.75 \mathrm{~kg}, p<0.001)$, TF $(-3.28 \mathrm{~kg}, p<0.001)$, and SMM $(-0.91 \mathrm{~kg}, p=0.003)$ tissue decreased in a different degree, leading to a small but highly significant increase in PSMM $(2.60 \%, p<0.001)$. A decrease in BF and SMM resulted in a significant reduction in BMI, while IH decreased in a smaller degree than BMI because PBF and PSMM changed inversely. Conclusion. Six weeks of a controlled exercise program 3 times/week and semi-controlled diet is an effective approach to the reduction of $\mathrm{BM}, \mathrm{BF}$, and $\mathrm{TF}$ and to increasing the movement potential by changing the proportions of PBF and PSMM.
\end{abstract}

Keywords: fat reduction, trunk fat, abdominal fat reduction, body composition, healthy nutrition.

\section{INTRODUCTION}

Human body composition consists of nearly 40 components divided in 5 levels, and all those components contact and interact between each other and play certain roles in the body [25]. Therefore, certain body composition components are often considered to be sensitive indicators of health and physical fitness $[2,10,11,16]$, wherein body fat mass (FM) is the biggest ballast tissue in contrast to skeletal muscle mass (SMM) which represent the main movement potential.

In an extensive review on anti-inflammatory effects of exercise, the association between the increased fatness (especially in the abdomen) and all-cause mortality, dementia, and several cancers were explained by an increase in the production of pro-inflammatory adipokines and reduced production of anti-inflammatory cytokines [11]. Furthermore, Garibalda et al. [10] observed signifi- cantly higher blood pressure, c-reactive protein levels, pro-inflammatory cytokine levels, and protein carbonyls contents and lower $\beta$-carotene levels among women in the fourth quartile than in the first quartile for body mass (BMI) and waist circumference WC $(p<0.01)$. On the other side, SMM is shown to be sports-specific in athletes $[2,9]$, and the significant predicting variable of general physical fitness in police officers [26]. Moreover, Dopsaj et al. showed that young waterpolo players were $5.01 \mathrm{~kg}$ heavier than the control group, most probably due to higher SMM, but also were exerting significantly higher hand grip forces. In contrast, ageing was found to be associated with a reduction in SMM which potentially may lead to disability and impairment in people with low amounts of SMM $[13,14]$.

However, various strategies of body compositon management have been investigated, and 


\section{Физиология}

the majority agrees that food intake together with the type and level of physical activity might be the most optimal ones [21]. In that regards, planned and continous implementation of individualized physical training programs $[12,23]$ and caloric restriction diets [20] or both $[8,12]$ were shown to be highly effective in reducing body mass (BM) but more importantly fat mass (FM). Conversely, application of resistance, aerobic, and combined training is reported to be an effective strategy in an increase of SMM and reduction of FM [26].

Although considerable research exists on the effects of exercise on the components of body composition from various institutionally organized studies, limited data is provided from a daily practice conducted in a training center. Thus, the aim of this study was to investigate the effects of a 6-week controlled personal exercise program followed by a recommended dietary regimen on indicators of FM and SMM in adults.

\section{METHODS}

This was a longitudinal applied observational study conducted on a random sample of adults under the monitoring of Kubo Training Center (KTC) from Belgrade, Serbia. Body composition parameters were collected on two occasions separated by 6 weeks of exercise program and semi-controlled diet regimen. All participants were trainees of KTC and were consequently working out for the minimum of 6 weeks in KTC, and each training session was closely monitored and controlled by the coaches of KTC. To meet the needs for the uniformity of training procedures, trainers from KTC had up to 3 months of introduction to work and training. Each participant had his own file where every testing session and exercise program were stored and afterwards transferred to a PC for further analysis.

\section{Sample}

The sample consisted of 28 particpants, 9 females and 18 males. The main characteristics of the sample were: age $=29.70 \pm 8.35$ years, body height $(\mathrm{BH})=177.35 \pm 9.36 \mathrm{~cm}$, and body mass $(\mathrm{BM})=105.20 \pm 27.06 \mathrm{~kg}$. All subjects were thoroughly briefed about the purpose of the study and were included in the analysis only if they agreed to it. Furthermore, before they joined the training process, they completed the medical examination and only if the board of medical doctors approved they were included in an exercise program. The research was carried out in accordance with the conditions of the declaration of Helsinki: Recommendations guiding physi- cians in biomedical research involving human subjects [4] and with the permission of the Ethics Committee (III 47015) of University of Belgrade, Faculty of Sport and Physical Education. Each participant was informed about the goals of this research and personally agreed to participate.

\section{Body composition measurements}

Body composition was measured using the method of direct segmental multi-frequency bioelectrical impedance analysis (BIA), employing the In Body 370 machine (Biospace, Co., Ltd, Seoul, Korea). The assessment occurred at the beginning and at the end of a 6-week exercise intervention. Trainees were instructed to have a light (or no) dinner and fast overnight prior to the body composition measurement and were restricted from fluid intake for 3 hours before the assessment. The assessment was conducted as previously reported in details $[6,9,26]$, whereby all participants fasted the night before the measurements being taken (6 to 9 am). Furthermore, the participants were barefoot, and had all metal, plastic, and magnetic accessories removed, stood on the device's spots designated for the feet. All body composition measurements were conducted in an indoor environment with a controlled temperature of $22{ }^{\circ} \mathrm{C}$. The absoulte measures of tissue volume such as body mass (BM), fat mass (FM), and skeletal muscle mass (SMM) were assesed and used to calculate relative measures of the tissue volume, percent of body fat (PBF), and percent of skeletal muscle mass (PSMM) and crude measures of body composition, body mass index (BMI), and index of hypokinezia (IH).

\section{Training protocol}

Participants were having three 90-min training sessions per week for 6 weeks, and training was organized in 3 main phases.

Phase 1: 10 minutes of cardio-respiratory, muscular and joint warmup, followed by dynamic flexibility and muscle activation using body weight exercises.

Phase 2: this phase consisted of circuit training and the exercises were executed in the way, so the participants never come to the exhaustion. Intensity fluctuated between $60-80 \%$ of 1 repetition maximum (RM), and the number of repetitons was $6-15$, respectively. Phase 2 of each program consisted of 6 exercises that were executed one after another. The rest between the exercises was chosen subjectively by the coach but within the range of 30-90 seconds. The order of the exercises was such that each next exercise was for a different group of muscles. For example, 
lower body pushes (squats variations, lounges) followed by the upper body pushes (push-ups, bench press, shoulder press) or isometric stomach exercises (plank, "dead bug", roll-out) followed by the lower body pulls (dead lift, swiss ball hamstring curls).

Phase 3: 25-30 minutes of aerobic training and 10 minutes of passive stretching. Intensity for the aerobic part of training was 65-75\% of maximal heart rate (MHR). MHR was estimated using calculation 220 - age $[14,19,21]$ and monitored by a polar heart rate monitor (Polar FT40) that was connected to the life fitness treadmill integrity series (Lifefitness, Brunswick, Co).

\section{Dietary recommendations}

All participants were introduced to a structured diet based on a low glycemic index (GI) and low glycemic load (GL) [1], which was shown to be a good choice for the management of diabetes, obesity, and cardiovascular disease $[3,7$, $18,22]$. Participants were provided by the written manual that divided the food into meats, vegetables, fruits, grains, dieries and juices that were further ordered by their GI. The manual was organized in colors, wherein tables with low GI nutrients were colored green, medium GI nutrients were colored yellow, while the tables with high GI nutrients were colored red. This way the participants were given a tool to navigate throughout the variety of nutritients on the market. Although, the participants were not closely monitored nor controled on the correctness of choices and amount of food they eat, they were instructed to choose the foods from the green tables (low amount of caloric and relatively fast sence of fullness) and to make the rest between the meals of about 4-6 hours [15]. At each training session participants were asked by the trainer to recall what they ate in as many details as possible. Moreover, trainers were available on the phone for consultations at all times. Water consumption instead of juices was encouraged but also not monitored.

\section{Statistics}

The effects of applied exercise program were tested using a Paired sample T-test from Statistical Package for Social Sciences (IBM, SPSS Statistics 20). The significance level was set at $p<0.05$. Effect size (ES) was calculated as differences in mean scores as a proportion of the standard deviation, following the formula: $\mathrm{ES}=\left(\mathrm{M}_{2}-\mathrm{M}_{1}\right) / \mathrm{SD}_{1}$, where $\mathrm{M}_{1}$ and $\mathrm{M}_{2}$ are the means of the groups being investigated. The magnitude of the effects was defined as follows: small $=0.2$, moderate $=0.6$, large $=1.2$, and very large $=2.0[24]$.

\section{RESULTS}

The descriptve statistics, mean, standard deviaiton (SD), minimum and maximum for all investigated variables at both testing occasions are shown in Table 1.

Applied exercise and semi-controlled diet program had a significant effect on reduction in absolute and relative indicators of the volume of body fat as well as muscle tissue (Table 2). The magnitudes of changes were higher in BF, $\mathrm{TF}$ and PBF than in SMM, which resulted in a significant increase in PSMM. In contrast, BMI and $\mathrm{IH}$ significantly decreased, with $\mathrm{IH}$ being changed to a lesser degree.

Descrtiptive statistics for the mean, standard deviation (SD), minimum and maximum

Table 1

\begin{tabular}{|l|c|c|c|c|c|c|}
\hline \multirow{2}{*}{ Variables } & \multicolumn{3}{|c|}{ TEST } & \multicolumn{3}{c|}{ RE-TEST } \\
\cline { 2 - 8 } & Mean \pm SD & Min & Max & Mean \pm SD & Min & Max \\
\hline BM (kg) & $105.50 \pm 26.60$ & 65.80 & 183.90 & $97.20 \pm 25.12$ & 61.90 & 176.50 \\
\hline BF (kg) & $37.4 \pm 14.88$ & 15.80 & 80.20 & $30.65 \pm 14.31$ & 12.30 & 76.70 \\
\hline SMM (kg) & $38.64 \pm 9.26$ & 22.40 & 59.70 & $37.73 \pm 9.22$ & 22.30 & 57.60 \\
\hline TF (kg) & $19.25 \pm 6.56$ & 7.80 & 36.40 & $15.97 \pm 6.93$ & 5.70 & 36.70 \\
\hline PBF (\%) & $34.88 \pm 7.18$ & 22.40 & 50.90 & $30.77 \pm 8.26$ & 19.30 & 48.20 \\
\hline PSMM (\%) & $37.09 \pm 4.20$ & 29.69 & 44.00 & $38.38 \pm 4.81$ & 29.18 & 45.71 \\
\hline BMI (kg/m $\left.{ }^{2}\right)$ & $33.24 \pm 7.01$ & 22.90 & 50.90 & $30.64 \pm 6.47$ & 21.50 & 48.90 \\
\hline IH (index unit) & $1.07 \pm 0.21$ & 0.75 & 1.52 & $1.01 \pm 0.22$ & 0.61 & 1.50 \\
\hline
\end{tabular}

Note: $\mathrm{BM}$ - body mass; $\mathrm{BF}$ - body far; $\mathrm{SMM}$ - skeletal muscle mass; TF - trunk fat; $\mathrm{PBF}$ - percent of body fat; PSMM - percent of skeletal muscle mass; BMI - body mass index; IH - index of hypokinezia; SD - standard deviation; Min - minimum; Max - maximum. 
Results of the Paired sample T-test

\begin{tabular}{|l|c|c|c|c|c|}
\hline \multicolumn{1}{|c|}{ Variables } & Difference & $\mathrm{cV}$ & $\mathrm{t}$ & $p$-value & ES \\
\hline BM (kg) & -8.30 & 39.11 & 13.529 & $<0.001$ & 0.31 \\
\hline BF (kg) & -6.75 & 48.98 & 10.804 & $<0.001$ & 0.45 \\
\hline SMM (kg) & -0.91 & 162.84 & 3.249 & 0.003 & 0.10 \\
\hline TF (kg) & -3.28 & 50.16 & 10.550 & $<0.001$ & 0.50 \\
\hline PBF (\%) & -4.11 & 66.07 & 8.009 & $<0.001$ & 0.57 \\
\hline PSMM (\%) & 1.29 & 105.42 & -5.034 & $<0.001$ & 0.30 \\
\hline BMI (kg/m ${ }^{2}$ ) & -2.60 & 42.30 & 12.509 & $<0.001$ & 0.37 \\
\hline IH (index unit) & -0.06 & 177.86 & 2.975 & 0.006 & 0.29 \\
\hline
\end{tabular}

Note: $\mathrm{BM}$ - body mass; $\mathrm{BF}$ - body far; SMM - skeletal muscle mass; TF - trunk fat; PBF - percent of body fat; PSMM - percent of skeletal muscle mass; BMI - body mass index; IH - index of hypokinezia; cV - coeffitient of variation; ES - effect size.

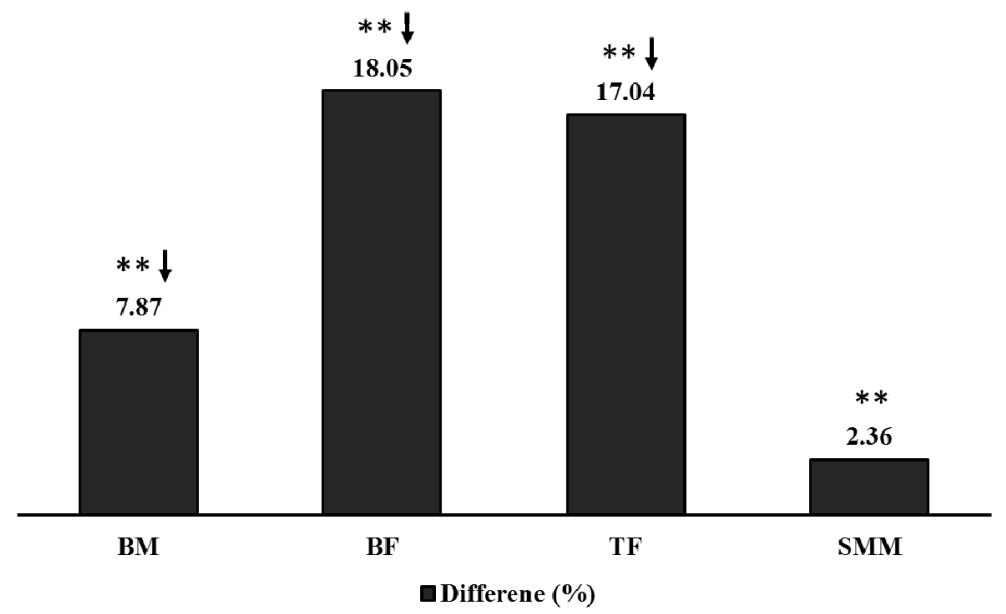

Fig. 1. Effects of an applied exercise program on BM, BF, TF and SMM. ** significant on $p<0.001, \downarrow-$ small positive and negative effect size

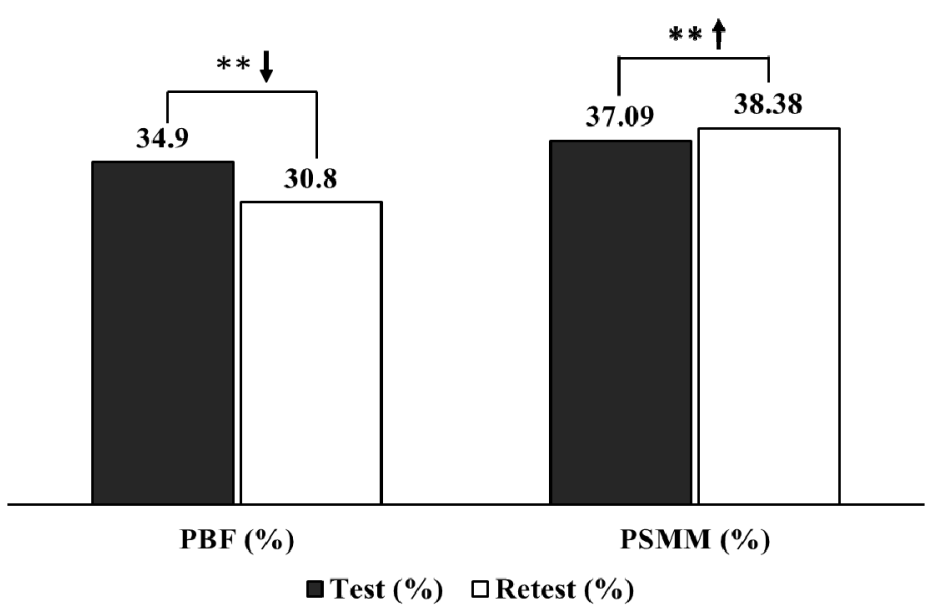

Fig. 2. Effects of an applied exercise program on PBF and PSMM.

** significant on $p<0.001, \uparrow$ and $\downarrow-$ small positive and negative effect size

Relative changes (\%) in BM occurred due to a significant, relative decrease in $\mathrm{BF}$, wherein a majority of decrease happened due to a reduction in TF. Relative changes occurred in SMM were also significant, but the magnitude of these changes was minimal (Fig. 1).

The difference in magnitudes of the applied exercise program on $\mathrm{BF}$ and SMM induced 


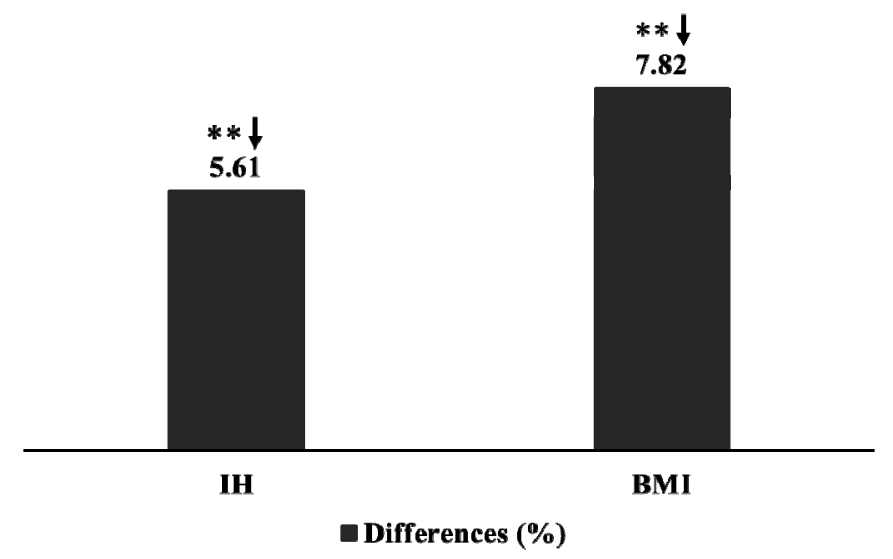

Fig. 3. Effects of an applied exercise program on IH and BMI. ** significant on $p<0.001$ and $\downarrow-$ small negative effect size

an inverse, small in magnitude but highly significant changes in PBF and PSMM (Fig. 2). Moreover, changes in relative amounts of fat and muscle tissue resulted in significant changes of small magnitude in BMI and IH (Fig. 3).

\section{DISCUSSION}

The main findings of this study strongly suggest that 6-weeks of a controlled exercise program together with a semi-controlled diet program can have a significant impact on specific components of body composition, which also reflects the level of the whole body. The amounts of BF, TF and SMM tissue decreased in different degree, leading to a small but highly significant $(p<0.001)$ increase in PSMM (Fig. 2). Furthermore, a decrease in both, BF and SMM tissue resulted in a significant reduction in BMI, while $\mathrm{IH}$ decreased in somewhat smaller degree than BMI because PBF and PSMM had inverse significant change (Fig. 3).

A paired sample t-test results revealed highly significant effects of the treatment which can be also noticed on the level of mean relative changes (Fig. 1-3), while calculated ES showed that the magnitudes of the effects were small for all investigated variables except for the SMM where the magnitude was minimal $(\mathrm{ES}<0.20)$. This could be due to a relatively significant $\mathrm{cV}$ in differences between the subjects, whereby the most significant $\mathrm{cV}$ occurred in SMM (Table 3). However, although the ES were small, and $\mathrm{cV}$ relatively large the applied treatment affected more than $99 \%$ of the smaple in all variables at the level of significance of $p<0.05$.

Regarding the effects of 6-weeks of a controlled exercise program together with a semicontroled diet program, our results are similar to those of Stojković et al. [23] who reported a re- duction of BM $(1.33 \mathrm{~kg}$ or $1.93 \%, p<0.001)$ after 8 weeks of the applied exercise program. The study design was similar comparing to our study with the difference being in no control for food at all in Stojković et al. [23]. Furthermore, Čvorović et al. [5] reported a reduction in BM $3.99 \mathrm{~kg}(5.06 \%, p<0.001)$, while Kukic et al. [16] found the positive effects of a 4-week exercise intervention on $\mathrm{BM}$ of female police officers $(0.92 \mathrm{~kg}$ or $1.14 \%, p=0.005)$. However, the study design was different because Čvorović et al. [9] and Kukic et al. [17] applied the training program on a group of people and did not control the food intake, while we had an individual program and semi-controlled diet.

Regarding the changes on a tissue level, Kukic et al. [17] reported a reduction in PBF of $2.26 \%(p=0.001)$ after a 4-week intervention, while Stojković et al. [23] reported a reduction in PBF of $2.33 \%(p<0.001)$ after a 8 -week exercise program. When applied a 16-week training program based on walking speeds close to preferred transition speed, Ilić et al. [12] showed a significant $(p<0.001)$ decrease in BM $(15.47 \mathrm{~kg}$ or $15.25 \%)$, BF (16.9 $\mathrm{kg}$ or $50 \%$ ), fat-free mass, PBF $(9.72 \%)$ and BMI $\left(5.06 \mathrm{~kg} / \mathrm{m}^{2}\right.$ or $\left.16 \%\right)$. Athough the study design had some similiraties such as the individual approach to each subject, the program duration was longer in Ilić et al. [12], and their subjects exercised 4 times/week. Furthermore, they controlled energy intake in the range of $1200-1500 \mathrm{kcal} / \mathrm{day}$, where 55 to $60 \%$ was provided from carbohydrates, 15 to $20 \%$ from proteins, and 20 to $25 \%$ from fat, and their participants spent more time walking on the treadmill [12]. Subjects from our study reduced BF mostly on acount of TF (hence abdominal fat), whose changes has not been often directly fol- 


\section{Физиология}

lowed in a multifactorial and hardly controllable setting such as a regular training center. In that regards, the KTC's approach seems to be effective not only from body composition but from a reduced health risk perspective as well [11]. Concludingly, analysis of our results in comparison to other longitudinal studies suggests that the length of the exercise program, level of diet control, type and organization of exercise program (individual or group) are all factors that can be manipulated in order to produce changes on a tissue level.

When it comes to SMM, our study, as well as studies that applied exercise program alone or followed by a controlled diet aimed at BM reduction $[6,8,12,23]$, showed a similarly small decrease in SMM compared to a loss in BF. A proclivity for a lower reduction rate of the absolute amount of muscle tissue resulted in an increase of the relative amount of muscular tissue (PSMM), positively affecting the movement potential. However, it is not clear if the decrease in SMM occurred due to the loss of dry contractile elements in early stages of adaptations to applied exercise given that initial 6 weeks followed by a semi-controlled diet may lead to a protein breakdown that precedes protein synthesis [26]. In that regards, more research is needed with deeper insight into muscular tissue in order to clearly explain the effects of a 6-week exercise program (mixed aerobic and resistance) and semi-controlled diet.

The changes in crude measures of body composition, BMI, and IH (Figure 3) are the result of treatment effects on a tissue level. Reduction of BM inevitably leads to a reduction of BMI, regardless of which tissue is affected and in what degree, although the proportion of tissues (PBF and PSMM) significantly changed. In contrast, IH was less affected than BMI by the applied treatment, probably because IH detects the inverse changes in tissue proportions and therefore, more meaningful changes than BMI [16].

\section{CONCLUSION}

The sample of the study was relatively small and consisted of a disproportional number of male and female subjects. Changes in BF and SMM may vary between the genders so separate analysis should be considered for more precise analysis. Individual effects of either applied exercise or diet were not investigated and should be also considered in the future. It could be generally concluded that 6 weeks of a controled exer- cise program and semi-controlled diet in approach one-on-one can be effective for the management of body composition. Furthermore, BF but more importantly TF can be well controlled by the implementation of three 90-minute training sessions per week consisted of aerobic and resistance exercises. Although PSMM increased, the absolute amount of skeletal tissue decreased, suggesting that for the maintenance or improvement of SMM, the applied treatment should be adjusted in 1 of 3 or in all 3 following ways: 1) applying the treatment for a longer time period (more than 6 weeks); 2) changing the diet; and 3 ) adjusting the variables within the exercise program.

\section{References}

1. Atkinson F.S., Foster-Powell K., BrandMiller J.C. International Tables of Glycemic Index and Glycemic Load Values. Diabetes Care, 2008, no. 31 (12), p. 2281.

2. Batueva A., Erlikh V., Pashnina A. Influence of Different Types of Circuit Training on the Functional Status and Anthropometric Parameters in Young Women with Obesity. Minerva Ortop Traumatol., 2018, vol. 69 (Suppl. 1 al N. 3), pp. 86-89. DOI: $10.23736 / \mathrm{S} 0394-$ 3410.17.03857-7

3. Brand-Miller J.C., Holt S.H., Pawlak D.B., McMillan J. Glycemic Index and Obesity. American Journal of Clinical Nutrition, 2002, no. 76 (1), pp. 281-285.

4. Christie B. Doctors Revise Declaration of Helsinki. BMJ, 2000, no. 321 (7266), p. 913.

5. Čvorović A., Kukić F., Orr R.M., Dawes J.J., Jeknić V., Stojković M. Impact of a 12-Week Postgraduate Training Course on the Body Composition and Physical Abilities of Police Trainees. Journal of Strength and Conditioning Research, 2018. DOI: 10.1519/JSC. 0000000000002834

6. Čvorović A., Orr R., Bacetić N. Effects of a 12-Week Physical Training Program and Nutrition Plan on the Body Composition of Overweight Police Trainees. In Proceedings: Archibald Reiss Days. Belgrade, Serbia: Academy of Criminalistic and Police Studies, Zemun, Belgrade; 2018, pp. 49-59.

7. de la Grandmaison G.L., Clairand I., Durigon M. Organ Weight in 684 Adult Autopsies: New Tables for a Caucasoid Population. Forensic Science International, 2001, no. 119, (2), pp. 149-154.

8. Demling R.H., DeSanti L. Effect of 
a Hypocaloric Diet, Increased Protein Intake and Resistance Training on Lean Mass Gains and Fat Mass Loss in Overweight Police Officers. Annals of Nutrition and Metabolism, 2000, no. 44, (1), pp. 21-29.

9. Dopsaj M., Markovic M., Kasum G., Jovanovic S., Koropanovski N., Vukovic M., Mudric M. Discrimination of Different Body Structure Indexes of Elite Athletes in Combat Aports Measured by Multi Frequency Bioimpedance Method. International Journal of Morphology, 2017, no. 35, (1), pp. 199-207.

10. Gariballa S., Alkaabi J., Yasin J., Al Essa A. Oxidative Damage and Associated Inflammatory Risk Factors in Obese Emirati Women. Body Mass Index Versus Waist Circumference. Saudi Medical Journal, 2017, no. 38, (9), pp. 960-964.

11. Gleeson M., Bishop N.C., Stensel D.J., Lindley M.R., Mastana S.S., Nimmo M.A. The Anti-Inflammatory Effects of Exercise: Mechanisms and Implications for the Prevention and Treatment of Disease. Natural Reviews. Immunology, 2011, no. 11, (9), pp. 607-615.

12. Ilić D., Ilić V., Mrdaković V., Filipović N. Walking at Speeds Close to the Preferred Transition Speed as an Approach to Obesity Treatment. Srpski Arhiv za Celokupno Lekarstvo. 2012, no. 140, (1-2), pp. 58-64.

13. Janssen I., Baumgartner R.N., Ross R., Rosenberg I.H., Roubenoff R. Skeletal Muscle Cutpoints Associated with Elevated Physical Disability Risk in Older Men and Women. American Journal of Epidemiology, 2004, no. 59, (4), pp. 413-421.

14. Janssen I., Heymsfield S.B., Wang Z., Ross R. Skeletal Muscle Mass and Distribution in 468 Men and Women Aged 18-88 yr. Journal of Applied Physiology. 2000, no. 89, pp. 81-88.

15. Kanikowska D., Sato M., Witowski J. Contribution of Daily and Seasonal Biorhythms to Obesity in Humans. International Journal of Biometeorology, 2015, no. 59, (4), pp. 377-384.

16. Kukic F., Dopsaj M., Dawes J., Orr R., Cvorovic A. Use of Human Body Morphology as an Indicator of Physical Fitness: Implicaitons for Police Officers. International Journal of Morphology, 2018, no. 36, (4), pp. 1407-1412.

17. Kukic F., Dopsaj M., Dawes J., Prcic D. Effects of a 4-week Training Intervention on Estimated $\mathrm{VO}_{2 \max }$ and Body Composition Among
Female Police Officers: Pilot Study. In Proceedings: Archibald Reiss Days. Belgrade, Serbia: Academy of Criminalistic and Police Studies, Zemun, Belgrade. 2018, pp. 39-48.

18. Ludwig D.S. The Glycemic Index: Physiological Mechanisms Relating to Obesity, Diabetes, and Cardiovascular Disease. JAMA. 2002, no. 287, (18), pp. 2414-2423.

19. Mesquita A., Trabulo M., Mendes M., Viana J.F., Seabra-Gomes R. The Maximum Heart Rate in the Exercise Test: the 220-age Formula or Sheffield's Table? Revista Portuguesa de Cardiologia, 1996, no. 15, (2), pp. 139-144.

20. Mraović T., Radaković S., Medić D.R., Ostojić V.T., Rađen S., Hajduković Z., Čairović A., Miljanović G. The Effects of Different Caloric Restriction Diets on Anthropometric and Cardiometabolic Risk Factors in Overweight and Obese Females. Vojnosanitetski Pregled., 2018, no. 75, (1), pp. 30-38.

21. Sacks G., Swinburn B., Lawrence M. Obesity Policy Action Framework and Analysis Grids for a Comprehensive Policy Approach to Reducing Obesity. Obesity Reviews, 2009, no. 10, (1), pp. 76-86.

22. Sheard N.F., Clark N.G., Brand-Miller J.C., Franz M.J., Pi-Sunyer F.X., MayerDavis E., Kulkarni K., Geil P. Dietary Carbohydrate (Amount and Type) in the Prevention and Management of Diabetes: A Statement by the American Diabetes Association. Diabetes Care, 2004, no. 27, (9), pp. 2266-2271.

23. Stojković M., Čvorović A., Jeknić V., Kukić F. Influence of Two-Month Training Program on Anthropometry and VO2max in Recreational Athletes. International Journal of Physical Education, Fitness and Sports, 2017, no. 6, (2), pp. 19-24.

24. Sullivan G.M., Feinn R. Using Effect Size - or Why the $P$ Value is Not Enough. Journal of Graduate Medical Education, 2012, no. 4, (3), pp. 279-282.

25. Wang Z.M., Pierson R.N., Heymsfield S.B. The Five-Level Model: a New Approach to Organizing Body-Composition Research. The American Journal of Clinical Nutrition, 1992, 56, (1), pp. 19-28.

26. Westcott W.L. Resistance Training is Medicine: Effects of Strength Training on Health. Current Sports Medicine Reports, 2012, no. 11, (4), p. 209.

Received 20 December 2018 


\title{
ВЛИЯНИЕ ШЕСТИНЕДЕЛЬНОЙ КОНТРОЛИРУЕМОЙ ПРОГРАММЫ УПРАЖНЕНИЙ И ЧАСТИЧНО КОНТРОЛИРУЕМОЙ ДИЕТЫ НА ЖИРОВУЮ МАССУ И МАССУ СКЕЛЕТНЫХ МЫШЦ У ВЗРОСЛЫХ
}

\author{
Ф. Кукич ${ }^{1}$, Н. Тодорович ${ }^{2}$, Н. Цвиянович ${ }^{2}$ \\ ${ }^{1}$ Спортивный образовательный центр полиции, полиция Абу-Даби, г. Абу-Даби, \\ Объединенные Арабские Эмираты, \\ ${ }^{2}$ Тренировочный центр Кубо, г. Белград, Сербия
}

\begin{abstract}
Цель. Целью данной статьи является установление влияния шестинедельной контролируемой программы упражнений, сопровождаемой частично контролируемой диетой, на показатели жировой массы и массы скелетных мышц у взрослых. Материалы и методы. Выборка состояла из 28 участников со следующими основными характеристиками: возраст $=29,70 \pm 8,35$ лет, рост $=177,35 \pm 9,36 \mathrm{~cm}$, вес $=105,20 \pm 27,06$ кг. Параметры состава тела были зарегистрированы до и после шестинедельной программы упражнений и частично контролируемой диеты: масса тела, жировая масса, жировая масса туловища, масса скелетных мышц, процент жировой массы, процент массы скелетных мышц, индекс массы тела и индекс гипокинезии. Для определения эффекта от используемой программы и его магнитуды применялся двухвыборочный t-тест для связанных выборок и оценка величины эффекта. Результаты. Шестинедельная программа оказала значительное влияние на исследуемые переменные, при этом жировая масса $(-6,75$ кг, $p<0,001)$, жировая масса туловища $(-3,28$ кг, $p<0,001)$ и масса скелетных мышц $(-0,91$ кг, $p=0,003)$ уменьшились в разной степени, что привело к небольшому, но статистически важному увеличению процента массы скелетных мышц $(2,60 \%, p<0,001)$. Снижение жировой массы и массы скелетных мышц привело к значительному понижению индекса массы тела, в то время как индекс гипокинезии снизился в меньшей степени, чем индекс массы тела, потому что процент жировой массы и процент массы скелетных мышц имеют обратную зависимость. 3аключение. Шесть недель контролируемой программы упражнений 3 раза в неделю и частично контролируемая диета являются эффективным подходом к снижению массы тела, жировой массы и жировой массы туловища, а также увеличивают двигательный потенциал за счет изменения соотношения процента жировой массы и процента массы скелетных мышц.

Ключевые слова: снижение жировой массы, жировая масса туловища, снижение жировой массы в области живота, состав тела, здоровое питание.
\end{abstract}

Филип Кукич, кандидат на присуждение степени $\mathrm{PhD}$, руководитель Спортивного образовательного центра полиции, служба подготовки, полиция Абу-Даби. Объединенные Арабские Эмираты, г. Абу-Даби, ул. Карама, Спортивный образовательный центр полиции, аб. ящик 253. E-mail: filip.kukic@gmail.com, ORCID ID: 0000-0002-8625-5375.

Неманя Тородович, магистр наук, операционный руководитель тренировочного центра Кубо. Сербия, Смедеревски пут 3-б, г. Белград, аб. ящик 11050. E-mail: nemanja.tod@ hotmail.com, ORCID ID: 0000-0003-4741-0966.

Ненад Цвиянович, магистр наук, руководитель по питанию тренировочного центра Кубо. Сербия, Смедеревски пут 3-б, г. Белград, аб. ящик 11050. E-mail: nenadcvijanovic89@ gmail.com, ORCID ID: 0000-0002-7196-6342.

Поступила в редакцию 20 декабря 2018 г.

\section{ОБРАЗЕЦ ЦИТИРОВАНИЯ}

Kukić, F. Effects of a 6-Week Controled Exercise Program and Semi-Controled Diet on Body Fat and Skeletal Muscle Mass in Adults / F. Kukić, N. Todorović, N. Cvijanović // Человек. Спорт. Медицина. - 2019. T. 19, № 1. - C. 7-14. DOI: 10.14529/hsm190101

\section{FOR CITATION}

Kukić F., Todorović N., Cvijanović N. Effects of a 6-Week Controled Exercise Program and Semi-Controled Diet on Body Fat and Skeletal Muscle Mass in Adults. Human. Sport. Medicine, 2019, vol. 19, no. 1, pp. 7-14. DOI: $10.14529 / \mathrm{hsm} 190101$ 